\title{
Phylogenetics of Trachylina (Cnidaria: Hydrozoa) with new insights on the evolution of some problematical taxa
}

\author{
ALlen G. COLLINS ${ }^{1}$, BASTIAN BENTLAGE ${ }^{2}$, ALBERTO LINDNER ${ }^{3}$, DHUGAL LINDSAY $^{4}$, \\ STEVEN H.D. HADDOCK ${ }^{5}$, GERHARD JARMS ${ }^{6}$, JON L. NORENBURG ${ }^{7}$, THOMAS JANKOWSKI $^{8}$ \\ AND PAULYN CARTWRIGHT ${ }^{2}$ \\ ${ }^{1}$ NMFS, National Systematics Laboratory, National Museum of Natural History, MRC-153, Smithsonian Institution, PO Box 37012 , \\ Washington, DC 20013-7012, USA, ${ }^{2}$ Department of Ecology and Evolutionary Biology, University of Kansas, 1200 Sunnyside \\ Avenue, Lawrence, KS 66045, USA, ${ }^{3}$ Centro de Biologia Marinha-USP-Rodovia Manoel Hipólito do Rego, Km 131, 5-São \\ Sebastião, SP, Brazil, ${ }^{4} J a p a n$ Agency for Marine-Earth Science and Technology (JAMSTEC), Yokosuka, Japan, ${ }^{5}$ Monterey Bay \\ Aquarium Research Institute, 7700 Sandholdt Road, Moss Landing, CA 95039, USA, ${ }^{6}$ Biozentrum Grindel und Zoologisches \\ Museum, Universität Hamburg, Martin-Luther-King Platz 3, 20146 Hamburg, Germany, ${ }^{7}$ Smithsonian Institution, PO Box 37012 , \\ Invertebrate Zoology, NMNH, W-216, MRC163, Washington, DC 20013-7012, USA, ${ }^{8}$ Federal Institute of Aquatic Science and \\ Technology, Dübendorf 8600, Switzerland
}

\begin{abstract}
Some of the most interesting and enigmatic cnidarians are classified within the hydrozoan subclass Trachylina. Despite being relatively depauperate in species richness, the clade contains four taxa typically accorded ordinal status: Actinulida, Limnomedusae, Narcomedusae and Trachymedusae. We bring molecular data (mitochondrial 165 and nuclear small and large subunit ribosomal genes) to bear on the question of phylogenetic relationships within Trachylina. Surprisingly, we find that a diminutive polyp form, Microhydrula limopsicola (classified within Limnomedusae) is actually a previously unknown life stage of a species of Stauromedusae. Our data confirm that the interstitial form Halammohydra sp. (Actinulida) is derived from holopelagic direct developing ancestors, likely within the trachymedusan family Rhopalonematidae. Trachymedusae is shown to be diphyletic, suggesting that the polyp stage has been lost independently at least two times within trachyline evolution. Narcomedusae is supported as a monophyletic group likely also arising from trachymedusan ancestors. Finally, some data, albeit limited, suggest that some trachyline species names refer to cryptic species that have yet to be sorted taxonomically.
\end{abstract}

Keywords: phylogenetics, Trachylina, problematic taxa

Submitted 29 November 2007; accepted 8 February 2008; first published online 8 September 2008

\section{INTRDDUCTION}

Molecular data continue to enhance our understanding of the evolutionary history of life at all hierarchical levels. Nevertheless, many questions about cnidarian phylogenetic relationships remain unanswered (Daly et al., 2007). To address these questions, and thereby provide a robust phylogenetic framework for addressing biological questions involving cnidarians, is the primary aim of the Cnidarian Tree of Life project (http://cnidarian.info). To achieve this goal, this large, collaborative effort is compiling molecular data from both nuclear and mitochondrial markers from as many cnidarian species as possible. This paper summarizes progress in understanding the phylogeny of Trachylina and provides greater insight into the evolution of several problematical cnidarians.

Within Hydrozoa (Cnidaria), an ancient phylogenetic divergence appears to have given rise to two primary clades with extant representatives, Trachylina and Hydroidolina

Corresponding author:

A.G. Collins

Email: CollinsA@SI.edu
(Collins, 2002; Collins et al., 2006a). In terms of species richness, the vast majority of hydrozoan diversity is contained within Hydroidolina (=Leptolina sensu Schuchert, 2007). Trachylina encompasses roughly 150 valid species, whereas Hydroidolina contains more than 3000 (Schuchert, 1998). Nevertheless, because of lack of study and generally simple and plastic morphology, the true species richness of Trachylina remains obscure, and significant levels of crypsis are possible. Interestingly, the numbers of higher taxa classified within Trachylina and Hydroidolina are comparable. Limnomedusae, Narcomedusae, Trachymedusae and Actinulida (though it has not been sampled for molecular data until this study) are the main taxa, usually ranked as orders, within Trachylina (Figures 1-3). Hydroidolina (see Cartwright et al., this volume) contains three relatively diverse clades, Anthoathecata (athecate hydroids and anthomedusae), Leptothecata (thecate hydroids and leptomedusae) and Siphonophora.

The diversity of life history and morphological features across Trachylina makes the group particularly interesting from an evolutionary perspective. For instance, the trachyline species that perhaps first come to mind are the oceanic, 
A

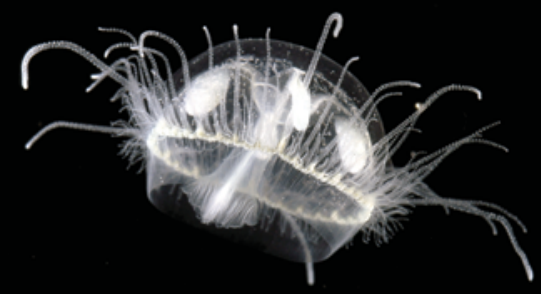

D

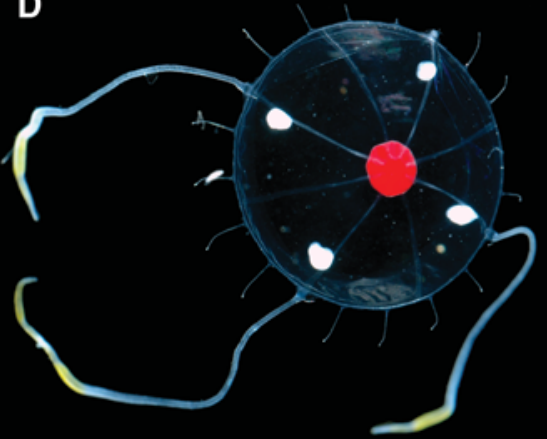

G

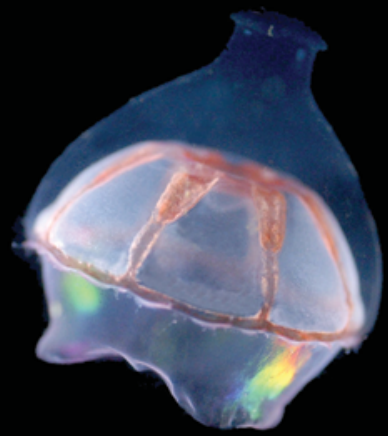

J

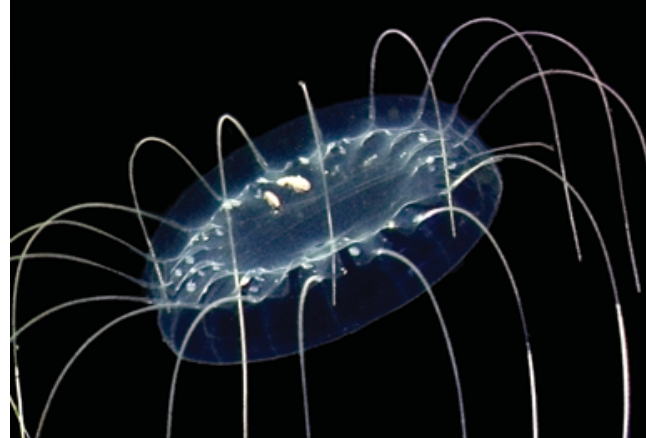

B

E

H

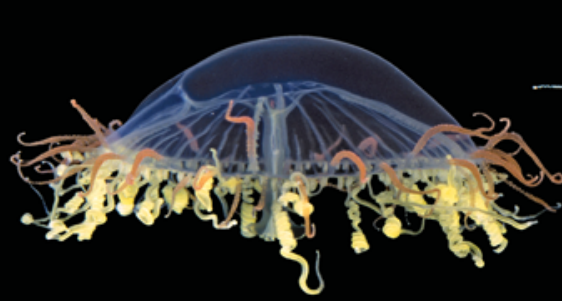

C
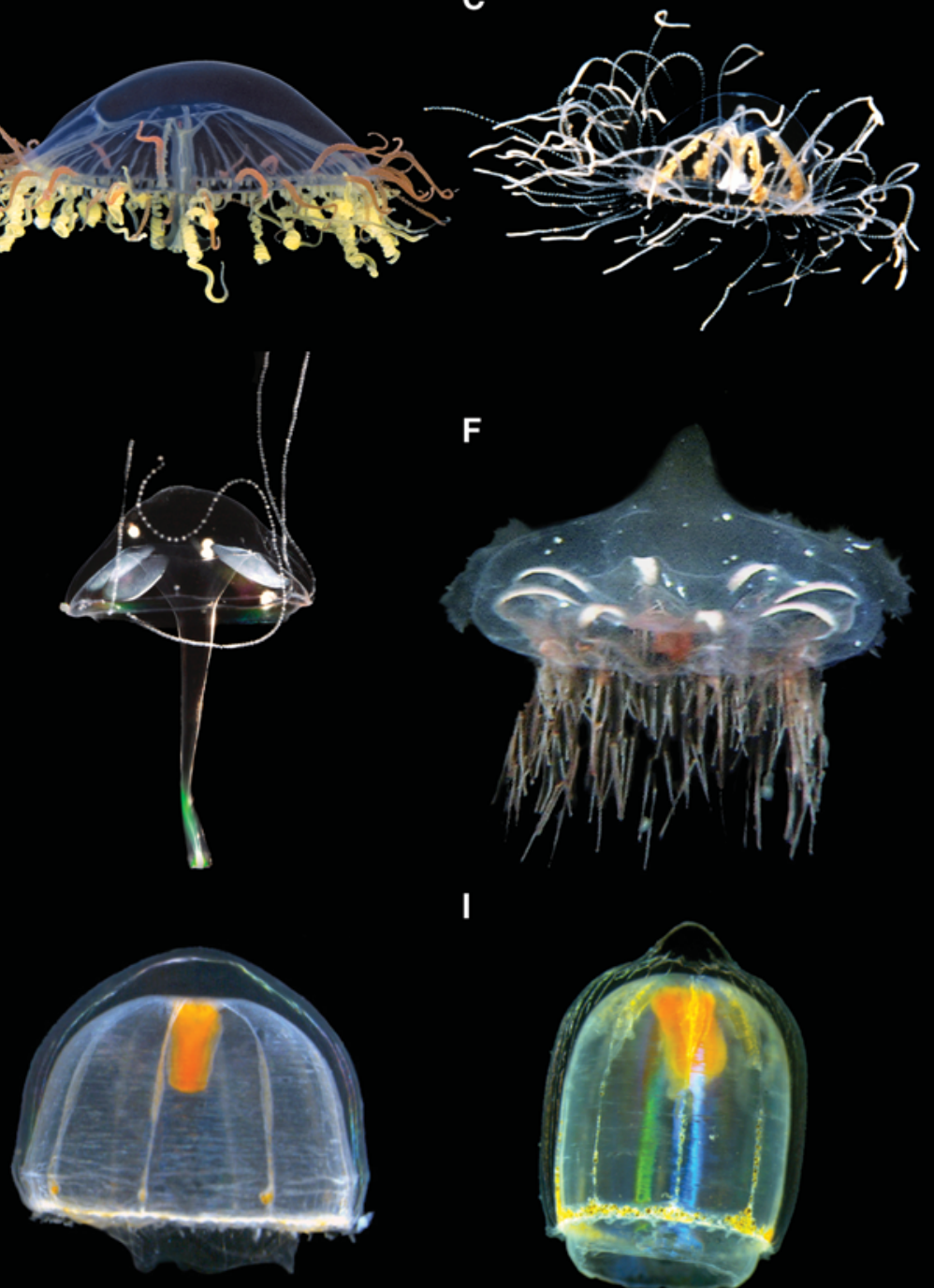

I
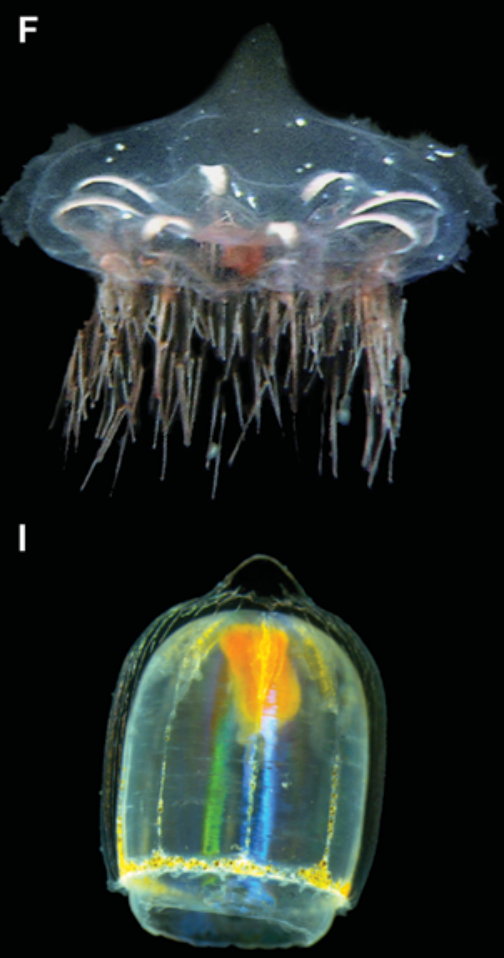

$\mathbf{L}$

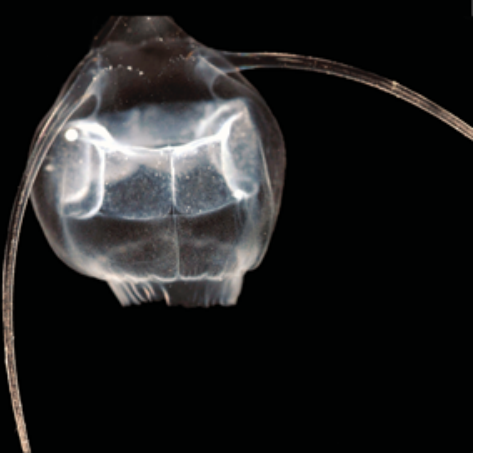

Fig. 1. Images of representative trachyline species. Note that the specimens depicted are not the ones DNA samples were obtained from. (A-C) Limnomedusae; (D-I) Trachymedusae; (J - L) Narcomedusae. (A) Craspedacusta sp.; (B) Olindias sambaquiensis; (C) Gonionemus vertens; (D) Tetrorchis erythrogaster; (E) Liriope tetraphylla; (F) Halicreas minimum; (G) Botrynema brucei; (H) Pantachogon 'white-red'; (I) Pantachogon 'orange'; (J) Solmissus incisa; (K) Aegina rosea; (L) Solmundella bitentaculata. A, B and E from A.E. Migotto (Centro de Biologia Marinha, Universidade de São Paulo); C from P. Schuchert (Muséum d'Histoire Naturelle de la Ville de Genève); D and L from S.H.D. Haddock (images captured in California); F-K from D. Lindsay (images captured in Japan).

holopelagic members of Trachymedusae and Narcomedusae, which usually develop directly from planula to adult. Even within these groups there are exceptions, e.g. the bentho-pelagic trachymedusans of the family Ptychogastriidae, narcomedusans with secondarily derived polypoid, parasitic life stages (Bouillon, 1987; Collins, 2002), and the highly unusual wormshaped narcomedusan Tetraplatia (Hand, 1955; Collins et al., 2006b) that bears four sets of swimming flaps. The only 


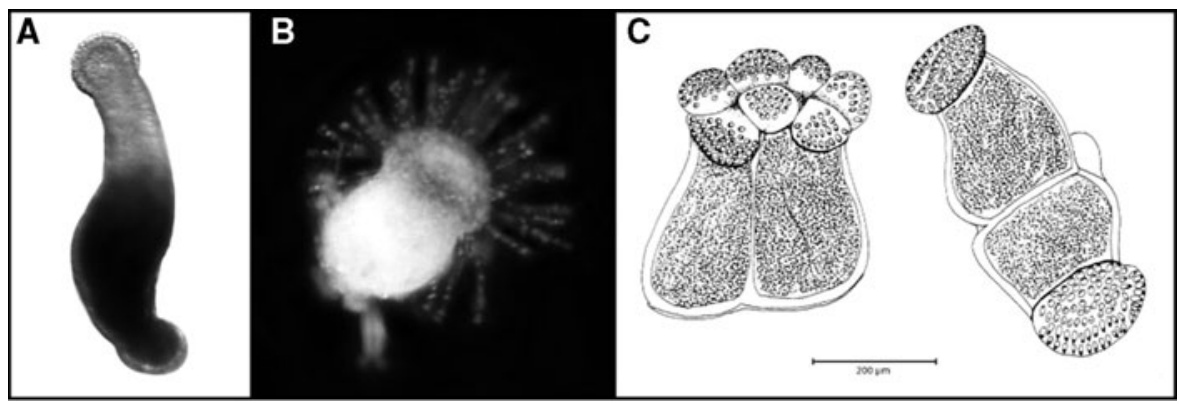

Fig. 2. (A) Polyp of Craspedacusta sowerbii; (B) polyp of Astrohydra japonica; (C) Microhydrula limopsicula modified from Jarms \& Tiemann (1996); left: cauliflower shaped polyp; right: polyps closely attached to their bivalve host.

species of Trachylina that possess a true polyp stage are those classified within Limnomedusae. Limnopolyps are generally tiny (less than $1 \mathrm{~mm}$ in length) and simple, laterally bud medusae like those of the hydroidolinan groups, and usually produce frustrules, creeping asexual larvae that disperse and metamorphose into additional polyps. Because the medusa stages of limnomedusans are very similar in morphology to those of Trachymedusae, the presence of a polyp stage is critical to differentiating the two taxa. Limnomedusae is also of note because several species live in fresh water, a relatively unusual habit for cnidarians (Jankowski et al., 2008).

Perhaps the most unusual trachyline species are those of Actinulida. These minute tentacled, ciliated and solitary forms spend their lives creeping between sand grains. Actinulidans, which develop directly from planulae to adults, were hypothesized to be living remnants of interstitial ancestral hydrozoans (Swedmark \& Tessier, 1966). In contrast, however, their possession of ecto-endodermal statocysts, and sometimes brood chambers have led most researchers in recent decades to conclude that they are more likely derived medusae that have been highly modified for their interstitial existence (e.g. Werner, 1965; Salvini-Plawen, 1987; Bouillon \& Boero, 2000; Marques \& Collins, 2004). However, their simple and derived morphology has prevented any definitive conclusions about their precise phylogenetic position within Trachylina, hindering our understanding of how these interesting species evolved.

A key step in understanding the evolution of trachyline diversity is the development of a robust hypothesis of phylogenetic relationships within and between the various trachyline taxa. By sampling numerous new species (including

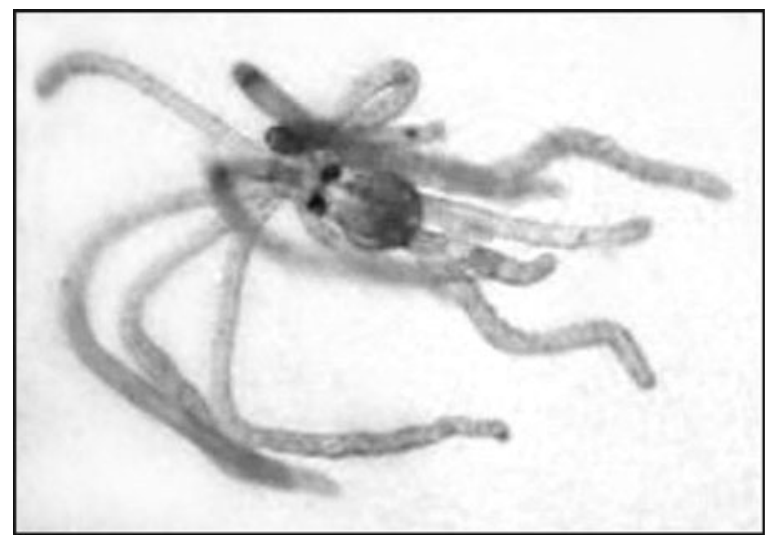

Fig. 3. Still image taken from a video of Halammohydra sp. by J. Norenburg. a member of Actinulida), for sequences of mitochondrial and nuclear markers, this study continues the effort to unravel the phylogeny of Trachylina, thereby providing insight into the evolutionary patterns underlying the diversity of trachyline life cycles and life history strategies.

\section{MATERIALS AND METHODS}

\section{Sampling}

Specimens included in this study have come from a diversity of sources (Table 1). Tissue samples were preserved in pure ethanol or frozen in liquid nitrogen and stored at $-80^{\circ} \mathrm{C}$. DNA was extracted using either commercially available extraction kits (DNAzol, Molecular Research Center, Inc.; Invisorb Spin Tissue kit, Invitek) or phenol/chloroform. For the latter, a small amount of tissue was incubated at $55^{\circ} \mathrm{C}$ for several hours or overnight in $500 \mu$ lysis buffer $(10 \mathrm{mM}$ Tris-HCl [pH 8.0], $1 \mathrm{mM}$ EDTA), $25 \mu \mathrm{LDS}$ (20\%) and $12.5 \mu \mathrm{l}$ of Proteinase-K $(20 \mathrm{mg} / \mathrm{ml})$. An equal volume of equilibrated phenol/chloroform (1:1) was then added to the homogenate. The reaction tube was subsequently inverted several times to allow mixing of the solution followed by 5 min of centrifugation at maximum speed. The upper, aqueous layer was then transferred into a new reaction tube. Optionally, $200 \mu \mathrm{l}$ of TE (10 mM Tris-HCl [pH 7.4], 1 mM EDTA [pH 8]) were added to the leftover layer of phenol/chloroform also followed by mixing and centrifugation in order to increase the overall yield of the extraction ('back-extraction' of the residual aqueous phase). An additional washing step with chloroform was then performed by adding solely chloroform to the recovered aqueous phases followed by mixing and centrifugation for five minutes. The aqueous phases of initial and 'backextraction' were pooled and the dissolved DNA was precipitated with ethanol (e.g. Mühlhardt, 2003 for a protocol), and the resulting pellet was eluted in $15-30 \mu \mathrm{l}$ of TE.

Genes coding for the large subunit of the mitochondrial ribosome (16S) and the nuclear genes coding for both the small ( $18 \mathrm{~S}$ or SSU) and large ( $28 \mathrm{~S}$ or LSU) ribosomal subunits were amplified and sequenced as described below. All PCR reactions contained 50 vol\% Taq PCR Master Mix (Qiagen, Valencia, California) and $0.5 \mu \mathrm{M}$ of each respective primer. A region of mitochondrial $16 \mathrm{~S}$ (approximately $640 \mathrm{bp}$ ) was amplified and sequenced with the primers $\mathrm{F}_{2}$ and $\mathrm{R}_{2}$ (Cunningham \& Buss, 1993), using a modified PCR profile $\left(94^{\circ} \mathrm{C} / 5 \mathrm{~min}\right.$; $\left(94^{\circ} \mathrm{C} / 50 \mathrm{~s}, 45^{\circ} \mathrm{C} / 50 \mathrm{~s}, 72^{\circ} \mathrm{C} / 60 \mathrm{~s}\right) \times 5$; $\left(94^{\circ} \mathrm{C} /\right.$ $\left.\left.50 \mathrm{~s}, 50^{\circ} \mathrm{C} / 50 \mathrm{~s}, 72^{\circ} \mathrm{C} / 60 \mathrm{~s}\right) \times 30 ; 72^{\circ} \mathrm{C} / 5 \mathrm{~min}\right)$. Near complete 
Table 1. Samples with GenBank accession and voucher numbers when available; *, derived for this study.

\begin{tabular}{|c|c|c|c|c|c|}
\hline Taxonomic hierarchy and species & & $16 S$ & $18 S$ & $28 S$ & Voucher \\
\hline \multicolumn{6}{|l|}{ Stauromedusae } \\
\hline Cleistocarpida & Craterolophus convolvulus & & AY845344 & $\mathrm{AY}_{920781}$ & USNM 1073330 \\
\hline Eleutherocarpida & Haliclystus octoradiatus & & AY845346 & AHo14894 & \\
\hline \multicolumn{6}{|l|}{ Scyphozoa } \\
\hline Coronatae & Atolla vanhoeffeni & & $\mathrm{AF}_{100942}$ & AYo26368 & \\
\hline Sematostomeae & Chrysaora melanaster & & $\mathrm{AF}_{358099}$ & AY920780 & \\
\hline \multicolumn{6}{|l|}{ Cubozoa } \\
\hline Carydeida & Carybdea rastonii & & $\mathrm{AF}_{358108}$ & AY920787 & \\
\hline Chirodrpida & Chironex fleckeri & & $\mathrm{AF}_{358104}$ & $\mathrm{AY}_{920785}$ & \\
\hline \multicolumn{6}{|l|}{ Hydrozoa } \\
\hline \multicolumn{6}{|l|}{ Hydroidolina } \\
\hline Candelabridae & Candelabrum cocksii & $\mathrm{AY}_{512520}$ & AY920758 & AY920796 & \\
\hline Proboscidactylidae & Fabienna sphaerica & AM183133.1 & AY920767 & AY920797 & \\
\hline Moerisiidae & Moerisia sp. & $\mathrm{AY}_{512534}$ & $\mathrm{AF}_{358083}$ & AY920801 & \\
\hline Porpitidae & Porpita sp. & $\mathrm{AY}_{512529}$ & $\mathrm{AF}_{358086}$ & AY920803 & \\
\hline Polyorchidae & Scrippsia pacifica & $\mathrm{AY}_{512551}$ & $\mathrm{AF}_{358091}$ & AY920804 & \\
\hline Laodiceidae & Melicertissa sp. & $\mathrm{AY}_{512515}$ & $\mathrm{AF}_{358075}$ & AY920798 & \\
\hline Prayidae & Nectadamas diomedeae & $\mathrm{AY}_{512512}$ & $\mathrm{AF}_{358068}$ & AYo26377 & \\
\hline \multicolumn{6}{|l|}{ Trachylina } \\
\hline \multicolumn{6}{|l|}{ Actinulida } \\
\hline Halammohydridae & Halammohydra sp. & $\mathrm{EU}_{293991^{*}}$ & $\mathrm{EU}_{301622^{*}}$ & $\mathrm{EU}_{301623^{*}}$ & USNM 1109974 \\
\hline \multicolumn{6}{|l|}{ Limnomedusae } \\
\hline Olindiasidae & Aglauropsis aeora & $\mathrm{EU}_{293973^{*}}$ & AY920754 & AY920793 & USNM 1073327 \\
\hline Olindiasidae & Astrohydra japonica & $\mathrm{EU}_{293975^{*}}$ & & AY920794 & G. Jarms culture \\
\hline Olindiasidae & Craspedacusta sowerbii & $\mathrm{EU}_{293971^{*}}$ & $\mathrm{AF}_{358057}$ & & USNM 1105483 \\
\hline Olindiasidae & Craspedacusta sinensis & $\mathrm{AY}_{512507}$ & $\mathrm{EU}_{247815^{*}}$ & & \\
\hline Olindiasidae & Craspedacusta ziguensis & EU293974 & & & USNM 1102057 \\
\hline Olindiasidae & Gonionemus vertens & EU293976* & & & \\
\hline Olindiasidae & Limnocnida tanganyicae & $\mathrm{EU}_{293972^{*}}$ & AY920755 & $\mathrm{AY}_{920795}$ & USNM 1075114 \\
\hline Olindiasidae & Maeotias marginata & $\mathrm{AY}_{512508}$ & $\mathrm{AF}_{358056}$ & $\mathrm{EU}_{247810^{*}}$ & \\
\hline Olindiasidae & Olindias phosphorica & $\mathrm{EU}_{293978^{*}}$ & AY920753 & $\mathrm{EU}_{247808 *}$ & MHNG 29811 \\
\hline Olindiasidae & Olindias sambaquiensis & EU293977* & $\mathrm{EU}_{247} 814^{*}$ & $\mathrm{EU}_{247809 *}$ & \\
\hline Microhydrulidae & Microhydrula limopsicola & $\mathrm{EU}_{294003 *}$ & $\mathrm{EU}_{247811^{*}}$ & & G. Jarms culture \\
\hline Monobrachiidae & Monobrachium parasiticum & $\mathrm{EU}_{292970^{*}}$ & $\mathrm{AY}_{920752}$ & & USNM 1074993 \\
\hline \multicolumn{6}{|l|}{ Narcomedusae } \\
\hline Aeginidae & Aegina citrea & EU293997* & $\mathrm{AF}_{358058}$ & $\mathrm{AY}_{920789}$ & \\
\hline Aeginidae & Aegina rosea & & $\mathrm{EU}_{247813^{*}}$ & & \\
\hline Aeginidae & Solmundella bitentaculata & EU293998* & & & USNM 1107456 \\
\hline Aeginidae & Solmundella bitentaculata & & $\mathrm{EU}_{247812^{*}}$ & $\mathrm{EU}_{247795^{*}}$ & MHNG 31746 \\
\hline Cuninidae & Cunina frugifera & & $\mathrm{AF}_{358059}$ & & \\
\hline Cuninidae & Sigiweddellia sp. & EU293996* & & $\mathrm{EU}_{247796^{*}}$ & \\
\hline Cuninidae & Solmissus incisa & $\mathrm{EU}_{294002^{*}}$ & & & USNM 1111080 \\
\hline Cuninidae & Solmissus marshalli & $\mathrm{EU}_{294001^{*}}$ & $\mathrm{AF}_{358060}$ & $\mathrm{AY}_{920790}$ & \\
\hline Tetraplatiidae & Tetraplatia volitans & $\mathrm{EU}_{293999^{*}}$ & DQ002501 & DQ002502 & KUMIP 314322 \\
\hline Tetraplatiidae & Tetraplatia sp. & $\mathrm{EU}_{294000^{*}}$ & & & \\
\hline \multicolumn{6}{|l|}{ Trachymedusae } \\
\hline Geryoniidae & Geryonia proboscidalis & $\mathrm{EU}_{293979 *}$ & $\mathrm{EU}_{247816^{*}}$ & $\mathrm{EU}_{247807^{*}}$ & \\
\hline Geryoniidae & Liriope tetraphylla & $\mathrm{AY}_{512510}$ & $\mathrm{AF}_{358061}$ & & \\
\hline Geryoniidae & Liriope tetraphylla & EU293980* & AY920756 & & USNM 1107457 \\
\hline Halicreatidae & Botrynema brucei & $\mathrm{EU}_{293982^{*}}$ & $\mathrm{EU}_{247822^{*}}$ & $\mathrm{EU}_{247798^{*}}$ & \\
\hline Halicreatidae & Haliscera conica & $\mathrm{EU}_{293981^{*}}$ & $\mathrm{EU}_{247825^{*}}$ & EU247797* & \\
\hline Halicreatidae & Halicreas minimum & $\mathrm{EU}_{293983^{*}}$ & $\mathrm{EU}_{247826^{*}}$ & & \\
\hline Rhopalonematidae & Aglantha digitale & $\mathrm{EU}_{293985^{*}}$ & $\mathrm{EU}_{247821^{*}}$ & $\mathrm{AY}_{920791}$ & USNM 1073329 \\
\hline Rhopalonematidae & Aglaura hemistoma & & $\mathrm{EU}_{247818^{*}}$ & $\mathrm{EU}_{247803} *$ & MHNG 31745 \\
\hline Rhopalonematidae & Aglaura hemistoma & EU293984* & $\mathrm{EU}_{247820^{*}}$ & $\mathrm{EU}_{247802 *}$ & KUMIP 314323 \\
\hline Rhopalonematidae & Amphogona apicata & EU293994* & & $\mathrm{EU}_{247801 *}$ & \\
\hline Rhopalonematidae & Crossota rufobrunnea & EU293986* & $\mathrm{EU}_{247824}{ }^{*}$ & $\mathrm{EU}_{247800 *}$ & \\
\hline Rhopalonematidae & Crossota rufobrunnea & $\mathrm{EU}_{293987^{*}}$ & $\mathrm{EU}_{247823^{*}}$ & EU247799* & \\
\hline Rhopalonematidae & Pantachogon haeckeli & & $\mathrm{AF}_{358062}$ & AY920792 & \\
\hline Rhopalonematidae & Pantachogon haeckeli & EU293988* & & & USNM 1111078 \\
\hline Rhopalonematidae & Pantachogon 'white-red' & EU293989* & $\mathrm{EU}_{247817^{*}}$ & $\mathrm{EU}_{247805^{*}}$ & \\
\hline Rhopalonematidae & Pantachogon 'orange' & EU293990* & & $\mathrm{EU}_{247806^{*}}$ & \\
\hline Rhopalonematidae & Rhopalonema velatum & $\mathrm{EU}_{293992 *}$ & $\mathrm{EU}_{247819^{*}}$ & $\mathrm{EU}_{247804}$ & \\
\hline Rhopalonematidae & Rhopalonema cf. velatum & $\mathrm{EU}_{293993^{*}}$ & & & USNM 1107461 \\
\hline Rhopalonematidae & Tetrorchis erythrogaster & $\mathrm{EU}_{293995^{*}}$ & & & USNM 1111077 \\
\hline
\end{tabular}

USNM, National Museum for Natural History, Smithsonian Institution; KUMIP, University of Kansas Natural History Museum, Division of Invertebrate Paleontology; MHNG INVE, Muséum d'Histoire Naturelle de la Ville de Genève. 
SSU (approximately $1800 \mathrm{bp}$ ) was amplified and sequenced according to Medlin et al. (1988). The original PCR profile was modified to $94^{\circ} \mathrm{C} / 4 \mathrm{~min} ;\left(94^{\circ} \mathrm{C} / 20 \mathrm{~s}, 57^{\circ} \mathrm{C} / 20 \mathrm{~s}, 72^{\circ} \mathrm{C} /\right.$ $1 \mathrm{~min} 45 \mathrm{~s}$ ) $\times 35 ; 72^{\circ} \mathrm{C} / 7 \mathrm{~min}$. Nearly complete LSU (approximately $3200 \mathrm{bp}$ ) was amplified in two parts using the primers F63mod (Medina et al., 2001) and R2084 (5'-AGA GCC AAT CCT TTT CC- $\left.3^{\prime}\right)$ in one PCR reaction and the primers $\mathrm{F}_{13} 83$ ( $5^{\prime}$-GGA CGG TGG CCA TGG AAG T- $3^{\prime}$ ) and R 3238 ( $5^{\prime}$-SWA CAG ATG GTA GCT TCG- $3^{\prime}$ ) in a second reaction. The temperature profile of each PCR was the following: $94^{\circ} \mathrm{C} /$ $5 \mathrm{~min} ;\left(94^{\circ} \mathrm{C} / 30 \mathrm{~s}, 45^{\circ} \mathrm{C} / 60 \mathrm{~s}, 72^{\circ} \mathrm{C} / 3 \mathrm{~min}\right) \times 30 ; 72^{\circ} \mathrm{C} / 10 \mathrm{~min}$ (modified from Medina et al., 2001). The LSU sequences were obtained with the previously published primers F63sq, F635, R635, R1411sq, R1630, F2076sq, F2766 (all from Medina et al., 2001), R2800 (Voigt et al., 2004) and the newly developed primers F1383, F1689 (5'-CTA AGM SRY AGG GAA AYT C-3'), R2084 and $\mathrm{R}_{3238}$. Purification of PCR products and sequencing were carried out at the laboratories of Cogenics (Houston, Texas). Sequences and collection data for the source specimens have been deposited to GenBank (see Table 1).

\section{Datasets}

In order to investigate different phylogenetic questions, assess levels of correspondence among the different phylogenetic markers, and derive the most robust phylogenetic hypothesis of Trachylina possible, we created five datasets. First, partial mitochondrial 16S, nuclear SSU, and nuclear LSU data for all taxa (Table 1) were aligned using MUSCLE (multiple sequence alignment with high accuracy and high throughput) (Edgar, 2004). No adjustments were made by eye. 'Conserved' positions for each of the alignments were identified using Gblocks vo.91 (Castresana, 2000) with default parameters, except that half the taxa were allowed to be gaps for any given position. Positions deemed non-conserved by Gblocks were excluded from phylogenetic analysis.

The first dataset analysed was constructed in order to conduct initial investigations of the phylogenetic placement of the actinulidan Halammohydra sp., which had been hypothesized by some authors to represent an anciently diverging lineage of Hydrozoa (Swedmark \& Tessier, 1966). Therefore, for this dataset, we combined both SSU and LSU data (for the regions over which we were able to derive data from Halammohydra, 1298 and 1032 nucleotides, respectively) from a diverse set of trachylines, seven representatives of Hydroidolina, and six non-hydrozoan representatives of Medusozoa, used as outgroups (see Figure 4). Non-hydrozoans were not included in any of the other datasets, which were constructed to conduct more detailed analyses of Trachylina phylogeny and to investigate the degree of correspondence between the different markers. The second through fourth datasets consisted of all available trachyline sequences for mitochondrial $16 \mathrm{~S}$, SSU, and LSU markers (Table 1), along with seven species representing the breadth of hydroidolinan (non-trachyline hydrozoan) diversity for outgroups (Figures 5-7).

The fifth and final dataset was used to derive the most robust phylogenetic hypothesis possible for Trachylina. This dataset combined data from all three markers for which at least SSU

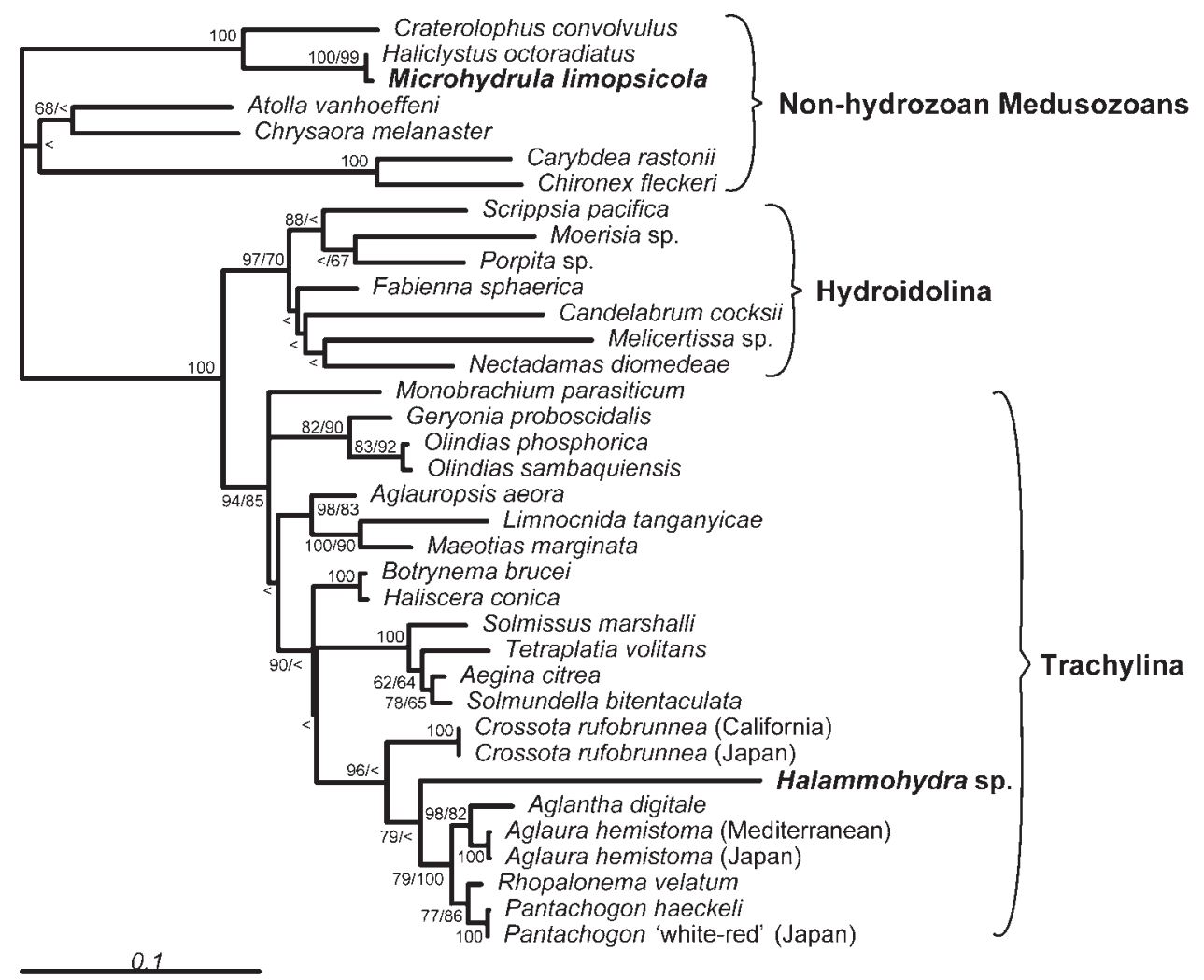

Fig. 4. Phylogenetic hypothesis with non-hydrozoan medusozoan outgroups to investigate the position of Halammohydra sp. within Hydrozoa. Note also the position of Microhydrula limopsicola. Phylogram of ML topology based on combined SSU and LSU data (dataset 1) with bootstrap indices under both ML and MP at each node. ' $<$ ' indicates a bootstrap index of less than 61 ; a single 100 or $<$ was placed at nodes if indices under both criteria were 100 or less than 61 , respectively. For ML analyses, the assumed model of nucleotide evolution was GTR + I + G. Scale bar is equivalent to o.1 substitutions per site. 


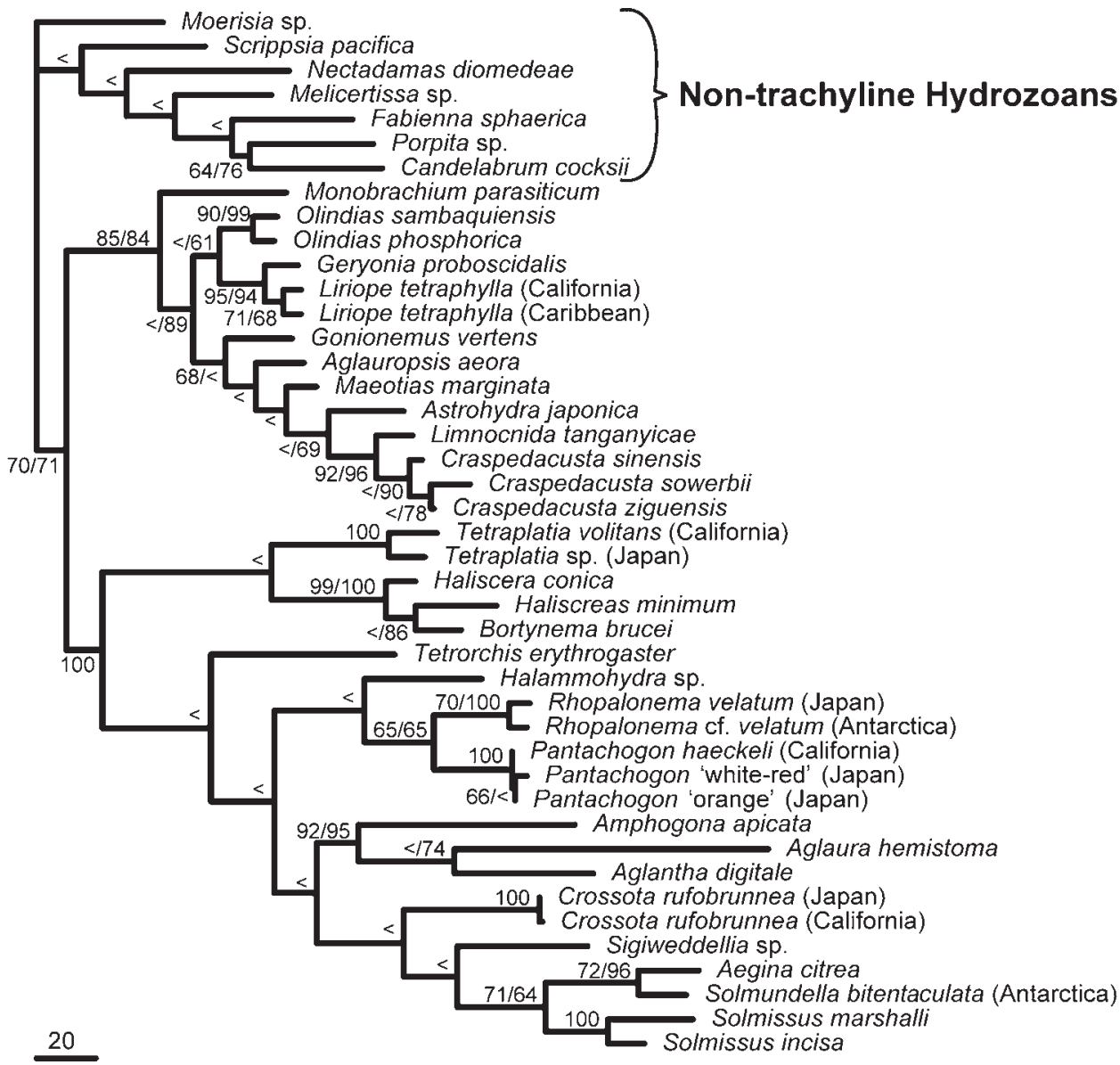

Fig. 5. Phylogenetic hypothesis based on mitochondrial $16 \mathrm{~S}$ data (dataset 2). Phylogram of one of the 20 most parsimonious trees, with bootstrap indices under both ML and MP at each node. ' $<$ ' indicates a bootstrap index of less than 61; a single 100 or $<$ was placed at nodes if indices under both criteria were 100 or less than 61, respectively. For ML analyses, the assumed model of nucleotide evolution was K81uf + I + G. Scale bar is equivalent to 20 substitutions.

or LSU had successfully been derived (Table 1; Figure 8), as well as the seven outgroup hydroidolinans for which all three markers were available. For this dataset, two chimerical sequences were constructed. Mitochondrial $16 \mathrm{~S}$ from Solmundella bitentaculata from Antarctica was combined with nuclear SSU and LSU of S. bitentaculata from the Mediterranean Sea. Mitochondrial 16S from Pantachogon haeckeli from the central coast of California was combined with un-vouchered Genbank SSU and LSU sequences derived from $P$. haeckeli from Californian coastal waters.

\section{Phylogenetic analyses}

Phylogenetic hypotheses were constructed under both maximum likelihood (ML) and maximum parsimony (MP) optimality criteria. Modeltest (Posada \& Crandall, 1998) was used, employing the Akaike information criterion, to choose the most appropriate model for each of the datasets. Assuming these models, PAUP* (Swofford, 2002) was used to search (with 100 random addition replicates) for the topology with the greatest likelihood and GARLI v0.951 (Zwickl, 2006) was used to calculate ML bootstrap indices from searches for 500 replicate datasets. PAUP* was further employed to find most parsimonious topologies, with 100 random replicate searches and to calculate bootstrap indices (500 replicates, with 10 searches per replicate).

\section{RESULTS}

In general, ML and MP topologies are congruent, only differing where bootstrap values are low under one or both criteria. Topologies, either ML or MP, for each of the five datasets are presented as Figures $4-8$. In addition, both ML and MP bootstrap indices are reported on these figures at each of the relevant nodes. Two main results are drawn from Figure 4 showing the ML topology for the combined SSU and LSU analysis including non-hydrozoan taxa as outgroups. First, the representative of Actinulida, Halammohydra sp., does not appear to be an early diverging lineage of Hydrozoa, but is instead revealed as a member of Trachylina. Second, Microhydrula limopsicola (classified in the family Microhydrulidae within Limnomedusae) is shown to not be a member of Hydrozoa at all, but instead to have a very close relationship to the stauromedusan Haliclystus octoradiatus.

Figure 5 presents one of $20 \mathrm{MP}$ trees based on our $16 \mathrm{~S}$ data. Generally, nodes in the topology do not receive high support. There is a well-supported split between two clades, one containing species of Limnomedusae plus species of the trachymedusan family Geryoniidae and the other comprising all the remaining trachymedusans, narcomedusans and the actinulidan Halammohydra sp. Other phylogenetic associations that receive method-independent (i.e. both MP and ML) support include: the limnomedusan genera Limnocnida and 


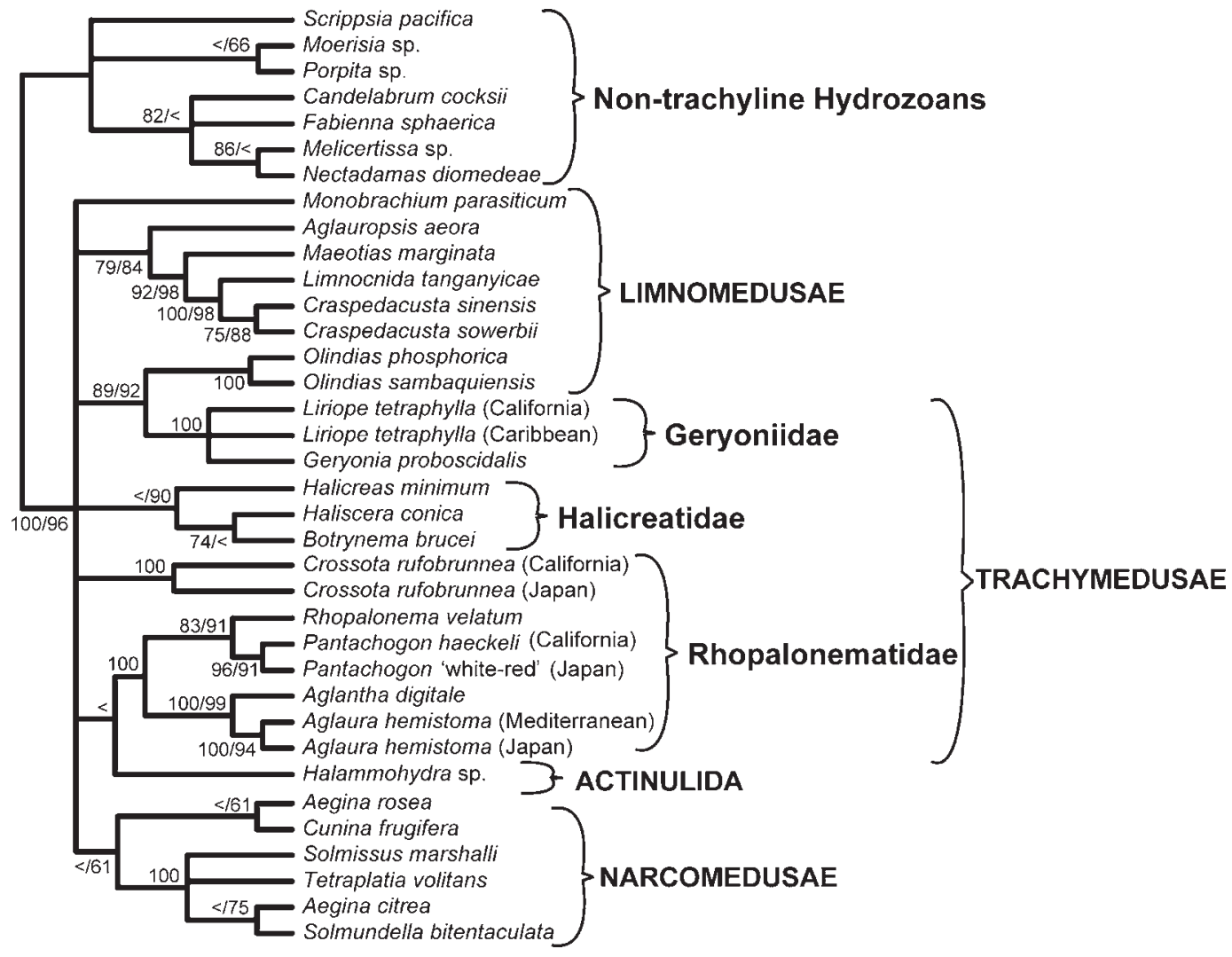

Fig. 6. Phylogenetic hypothesis based on SSU data (dataset 3). Strict consensus of the 21 most parsimonious trees, with bootstrap indices under both ML and MP at each node. ' $<$ ' indicates a bootstrap index of less than 61 ; a single 100 or $<$ was placed at nodes if indices under both criteria were 100 or less than 61 , respectively. For ML analyses, the assumed model of nucleotide evolution was GTR + I + G.

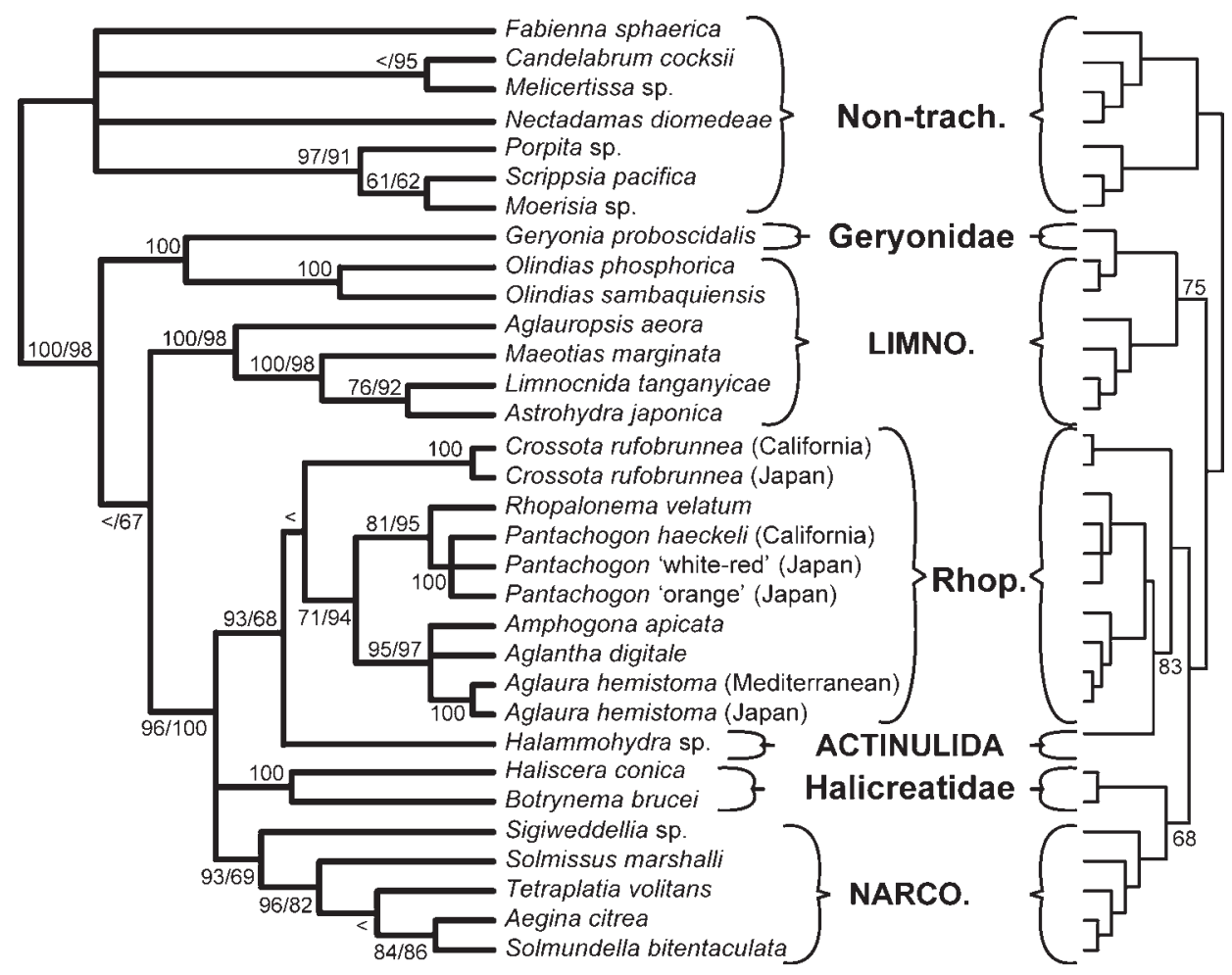

Fig. 7. Phylogenetic hypotheses based on LSU data (dataset 4). Left: strict consensus of the 12 most parsimonious trees with bootstrap indices under both ML and MP at each node. ' $<$ ' indicates a bootstrap index of less than 61 ; a single 100 or $<$ was placed at nodes if indices under both criteria were 100 or less than 61 , respectively. For ML analyses, the assumed model of nucleotide evolution was GTR + I + G. Right: ML topology with ML bootstrap indices for three nodes receiving support under ML but not under MP; terminal taxa in the same order as shown on the left. 


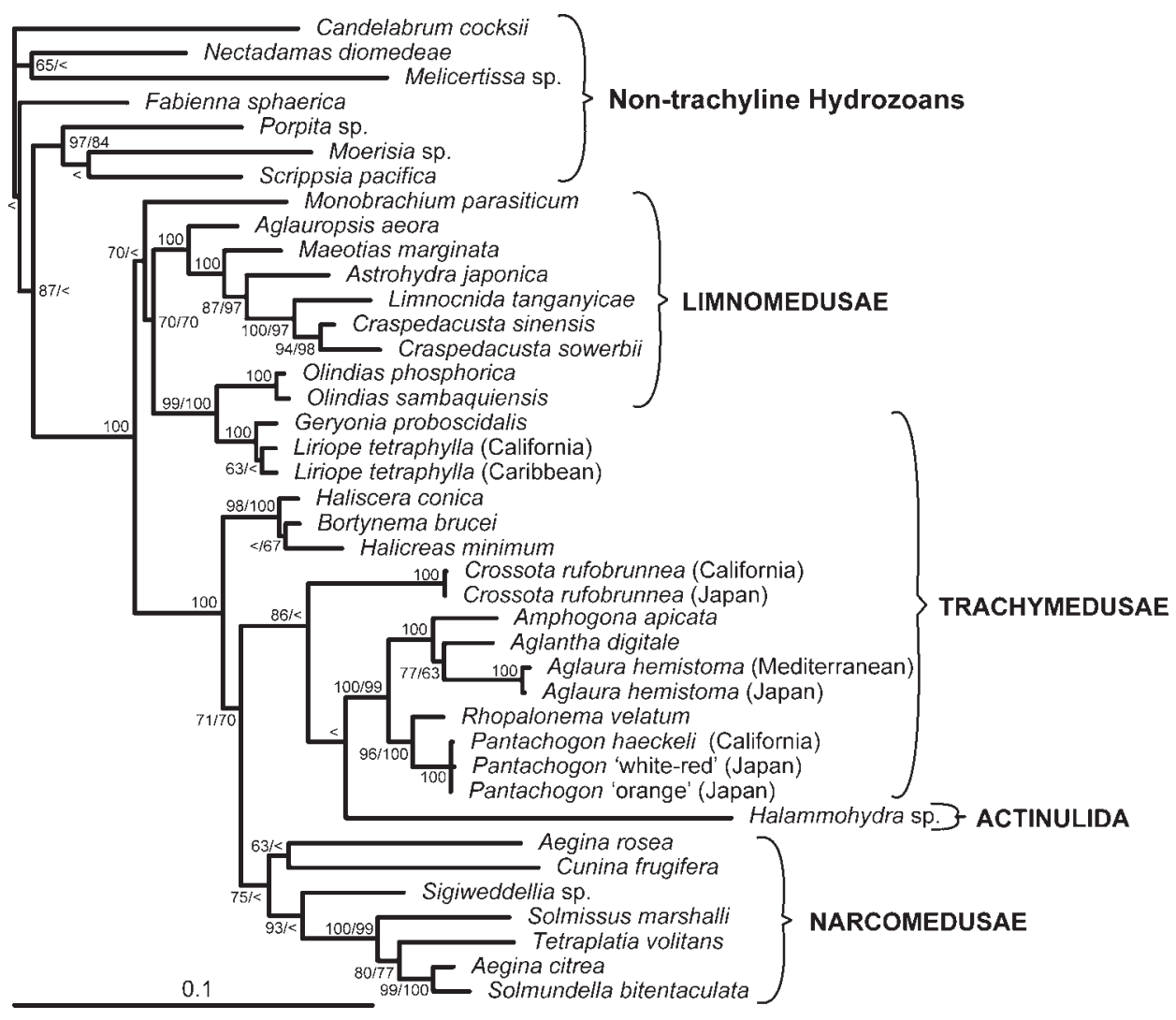

Fig. 8. Phylogenetic hypothesis based on combined $16 \mathrm{~S}$, SSU, and LSU data (dataset 5). Phylogram of ML topology, with bootstrap indices under both ML and MP at each node. ' $<$ ' indicates a bootstrap index of less than 61 ; a single 100 or $<$ was placed at nodes if indices under both criteria were 100 or less than 61, respectively. For ML analyses, the assumed model of nucleotide evolution was GTR $+\mathrm{I}+\mathrm{G}$. Scale bar is equivalent to 0.1 substitutions per site.

Craspedacusta; the trachymedusan genera Geryonia and Lirope (Geryoniidae); the trachymedusan genera Haliscera, Halicreas and Botrynema (Halicreatidae); the trachymedusan genera Rhopalonema and Pantachogon; the trachymedusan genera Amphogona, Aglaura and Aglantha; and, the narcomedusan genera Aegina, Solmundella and Solmissus.

Figure 6 shows the strict consensus of 21 MP trees found in searches using the SSU dataset. With three exceptions, all of the relationships strongly supported by the mitochondrial $16 \mathrm{~S}$ analyses (Figure 5) receive method independent support from the SSU data. The first exception is that there is no support for the splitting of Trachylina into two main clades. The second exception is that the ML bootstrap support for the node linking Haliscera, Halicreas and Botrynema (Halicreatidae) is only 54. The third exception is that the clade linking Aegina citrea, Solmundella and Solmissus also includes Tetraplatia volitans, which had an uncertain position based on the $16 \mathrm{~S}$ data. Additional clades receiving support, as measured by both MP and ML bootstraps are: the limnomedusan taxa Aglauropsis (marine) and Maeotias (brackish) with the freshwater Craspedacusta and Limnocnida; the limnomedusan genus Olindias with Geryoniidae; and, the two trachmedusan clades (Rhaopalonema + Pantachogon and Amphogona + Aglaura + Aglantha $)$.

The strict consensus of $12 \mathrm{MP}$ trees based on the LSU data supports many of the relationships also indicated by the $16 \mathrm{~S}$ and SSU analyses (Figure 7). One of the two main trachyline clades (non-geryoniid trachymedusans, narcomedusans and the actinulidan Halammohydra sp.) suggested by $16 \mathrm{~S}$ is also supported by LSU data. Two additional clades that receive high bootstrap support from LSU data under both MP and ML criteria are: all sampled representatives of Rhopalonematidae plus Halammohydra sp.; and, all sampled representatives of Narcomedusae.

Finally, Figure 8 shows the ML topology using the combined dataset. Given the great amount of correspondence between the different single-marker analyses, it is not surprising that this combined analysis contains nearly all of the associations enumerated above. In total comparing across all the single-marker analyses, there is only one instance of relationships receiving strong contradictory support. The SSU, LSU and combined data support an alliance of Aegina citrea, Solmundella, Solmissus and Tetraplatia volitans, whereas the $16 \mathrm{~S}$ analyses suggested that the first three taxa form a well-supported clade exclusive of Tetraplatia.

\section{DISCUSSIDN}

\section{Scope of Limnomedusae}

Limnomedusae has a somewhat complicated taxonomic history that reflects uncertainty about the phylogenetic affinities of the groups that constitute it, as well as confusion arising from the historical use of separate taxonomic systems by experts on hydromedusae and hydroids. The taxon was created in the late 1930s (Kramp, 1938; Browne \& Kramp, 1939) for species 
of the families Moerisiidae, Olindiasidae (=Olindiidae) and Proboscidactylidae. The underlying concept of Limnomedusae was that it should receive species with a biphasic life cycle, whose medusae did not fit the Anthoathecata (=Anthomedusae or Athecata) because they had either ecto-endodermal statocysts or gonads along their radial canals, and whose polyps did not fit the Leptothecata (=Leptomedusae or Thecata) because they lacked a theca. Subsequently, Monobrachiidae, which also meets the criteria above, has been added to Limnomedusae (Naumov, 1960), as have the small and simple species of Armorhydridae and Microhydrulidae, for lack of better alternatives (Bouillon, 1985). More detailed analysis that included information on the cnidome indicated that Moerisiidae is more likely to share a recent common ancestry with members of the anthoathecate group Capitata (Rees, 1958; Petersen, 1990). Likewise, the absence of statocysts and the presence of desmonemes strongly favour the hypothesis that Proboscidactylidae is closely related to anthoathecate species classified as Filifera (Edwards, 1973; Schuchert, 1996). Recently, molecular data have confirmed that Moerisidae and Proboscidactylidae do not belong in Limnomedusae (Collins et al., 2006a), thereby limiting its scope to Armorhydridae, Microhydrulidae, Monobrachidae and Olindiasidae. To a certain extent, our results (Figures 4-8) challenge this view of Limnomedusae, as further discussed below.

\section{Microhydrula limopsicola is a species of Stauromedusae}

Microhydrula limopsicola (originally classified within Limnomedusae) is an Antarctic species that possesses minute polyps found living on bivalve shells (Jarms \& Tiemann, 1996; Figure $2 \mathrm{C}$ ). The polyps are less than $0.5 \mathrm{~mm}$ in length and $0.35 \mathrm{~mm}$ in diameter and solitary, though they do form aggregates. The morphology of the polyps is quite simple as they lack tentacles and possess just a single type of nematocyst, microbasic euryteles. These polyps were observed to rest on a thin periderm and produce creeping, asexual frustules (Jarms \& Tiemann, 1996). The polyps of Limnomedusae (where known) are tiny, often without tentacles (e.g. Figure 2A), capable of producing frustules, and typically armoured with microbasic euryteles. This suite of features therefore suggests that M. limopsicola should be part of Limnomedusae. Thus, it is quite surprising that genetic data taken from samples of M. limopsicola strongly indicate that it is actually part of the non-hydrozoan Stauromedusae (Figure 4).

Concern that this result was a product of contamination prompted a re-sampling of a culture of Microhydrula limopsicola maintained in the Jarms laboratory. This yielded the same data, indicating that $M$. limopsicola is a member of Stauromedusae. In fact, in an ongoing study of Stauromedusae, mt16S data (Collins et al., unpublished data) identify $M$. limopsicola as a member of the genus Haliclystus, with a very close relationship to the species of Haliclystus from southern Chile reported on by Zagal (2004).

The most straightforward way to reconcile the interpretation of M. limopsicola as described by Jarms \& Tiemann (1996) is that it likely represents a microscopic life cycle stage not previously known in Stauromedusae. This would explain why no gonads were observed by Jarms \& Tiemann (1996). Life cycles of stauromedusans (and indeed most cnidarians) are not well known or documented. In particular, the juvenile stages of very few stauromedusan species are known. The only case for which the actual habitat of juvenile stauropolyps is known is for two species of Stylocoronella, whose polyps live interstitially (Salvini-Plawen, 1987; Kikinger \& Salvini-Plawen, 1995). Euryteles are widely distributed across Medusozoa, including Stauromedusae, so this character is not difficult to reconcile. However, this would appear to be the first time that a periderm and frustules have been recognized in any species of Stauromedusae. Both features are known from species within Discomedusae (Scyphozoa) and Limnomedusae (Hydrozoa) suggesting that they have evolved independently at least two times.

It is unclear if this result could be extended to other species of Microhydrulidae, the limnomedusan family to which M. limopsicola was assigned. The family contains just three species in two genera, and no adults or sexual reproduction have been reported from any of them. Microhydrula pontica is very similar in morphology to M. limopsicola and it may be that this species too, known from the northern Atlantic, represents another species of Stauromedusae. Rhaptapagis cantacuzeni, the third representative of the family, is differentiated from the other species by the possession of an unusual form of microbasic euryteles known as semiophores (Bouillon \& Deroux, 1967). DNA sampling of these taxa should help to resolve phylogenetic affinities of these species.

\section{Freshwater limnomedusans}

We present some new mt16S data for freshwater limnomedusans. These data further reinforce (albeit with low support) the hypothesis that freshwater limnomedusans had a single evolutionary origin (Figure 5, but note the robust support in Figure 8). Among our $16 \mathrm{~S}$ samples is a representative of Craspedacusta ziguensis. As reviewed by Jankowski (2001), the validity of this species has been in doubt. However, our mt16S data, which include representatives of two other readily accepted species of Craspedacusta, C. sowerbii and $C$. sinensis, indicate that $C$. ziguensis has comparable divergences from these two species ( $P$ distances of $7.4 \%$ and $6.1 \%$, respectively) as they do from each other (8.8\%). The SSU and 16 S data show Craspedacusta to have a close relationship to the freshwater genus Limnocnida. The polyps of the two genera are nearly indistinguishable: they are diminutive ( $1 \mathrm{~mm}$ or less in length), form small colonies up to seven individuals, lack tentacles, possess papillae with eurytele nematocysts at their oral ends, and produce creeping frustules that develop into additional polyps (Bouillon, 1957). The other freshwater species sampled here, Astohydra japonica, also produces frustules, but the polyps are smaller (up to $0.3 \mathrm{~mm}$ in length), solitary, and have 10 to 20 nematocyst-rich tentacles composed of single cells that may be homologous with the papillae of Craspedacusta and Limnocnida polyps (Hashimoto, 1981). The polyps of Astrohydra japonica and those of another freshwater genus, Calpasoma (not yet sampled for molecular data), are indistinguishable, and if it were not for the presence of a poorly known medusa stage in the former (Hashimoto, 1985), the two would have to be considered conspecific. 


\section{Geryoniidae (Trachymedusae) is derived from within Limnomedusae}

The medusae of Trachymedusae and Limnomedusae are quite similar, with gonads typically on the radial canals and statocysts of ecto-endodermal origin. The two differences between the groups are the presence or absence of a polyp stage and hollow or solid marginal tentacles in Limnomedusae and Trachymedusae, respectively (Schuchert, 2007). As a practical matter, the two groups can often be separated based on the number of radial canals, with most species of Limnomedusae possessing four (rarely six) and most species of Trachymedusae having eight (but some with four or six). We have found strong evidence that Geryoniidae is the sister group to species of the limnomedusan genus Olindias (Figures 4-8), whereas our analyses weakly favour the hypothesis that Limnomedusae plus Geryoniidae forms a clade with Monobrachium as its earliest diverging lineage (Figures 4 \& 8).

Interestingly, Geryoniidae is one of the two families of Trachymedusae with species not characterized by having eight radial canals, but rather four (Liriope) or six (Geryonia). Moreover, species of Geryoniidae have both solid and hollow marginal tentacles, as well as centripetal canals. Therefore, in most respects Geryoniidae can readily be incorporated within Limnomedusae. It has long been known that members of Geryoniidae lack a polyp stage (e.g. Brooks, 1886) and this appears to be the major difference between the group and members of Limnomedusae. Given our phylogenetic results, it would appear that a polyp stage was likely lost independently in Geryoniidae and the lineage leading to the other trachymedusans.

\section{Scope of Trachymedusae}

As presently constituted, Trachymedusae comprises five families, Geryoniidae, Halicreatidae, Petasidae, Ptychogastriidea and Rhopalonematidae. Our analyses contain members of three of these families; we have yet to sample Petasidae and Ptychogastridae. Besides Geryoniidae, the other group of trachymedusans without eight radial canals is Petasidae. Petasids have four radial canals, raising the possibility that they could potentially fall with Geryoniidae within Limnomedusae. However, they lack other features (hollow tentacles, centripetal canals) that could give credence to such a hypothesis. Ptychogastriids are somewhat more typical of Trachymedusae, possessing eight radial canals. But these species are bentho-pelagic and have features (such as tentacles with adhesive discs) that appear to be adapted for such an existence. Several members of Limnomedusae (Olindias, Gonionemus and Vallentinia, etc.) also spend considerable time resting on substrates, prompting one to question if ptychogastriids too might be closely related to or derived from within Limnomedusae.

Our analyses find strong support for the hypothesis that Halicreatidae and Rhopalonematidae form a clade with Narcomedusae and the interstitial Halammohydra sp. (Figures $7 \& 8)$. The best sampled family in our analyses is Rhopalonematidae. A close alliance appears to exist between Aglantha, Aglaura and Amphogona, all of which have a gastric peduncle and pendant gonads. Our data also suggest a relatively close relationship between Pantachogon and Rhopalonema, and that these two genera form a clade with
Aglantha plus Aglaura plus Amphogona. Among our samples of Rhopalonematidae, Crossota appears to be the earliest diverging lineage. Interestingly, in many of our analyses, the unusual interstitial Halammohydra (Actinulida) is shown as having had an origin within Rhopalonematidae. In all of our analyses, representatives of Halicreatidae form a well supported clade. Our combined data analyses suggest that this family is the sister group of a clade containing Narcomedusae, Halammohydra and the rhopalonematids (Figure 8).

\section{Halammohydra may be derived from within Rhopalonematidae (Trachymedusae)}

Species of Halammohydra were among the first cnidarians discovered to inhabit the interstices of sand grains (Remane, 1927). Subsequent studies have led to the discovery of additional species of interstitial hydrozoans (e.g. Swedmark, 1964; Clausen, 1971; Norenburg \& Morse, 1983). Otohydra, discovered off Roscoff, was grouped with Halammohydra in the order Actinulida by Swedmark \& Tessier (1958). In their view (Swedmark \& Tessier, 1966), these small and simple animals were representatives of the earliest diverging hydrozoan lineages, which themselves were inhabitants of the interstitial environment. In contrast, the presence of features including solid tentacles, ecto-endodermally derived statocysts, and lack of asexual reproduction, have been regarded as evidence that actinulids may be related to free-swimming Narco- and Trachymedusae (e.g. Remane, 1927; Werner, 1965; Salvini-Plawen, 1987; Bouillon \& Boero, 2000; Marques \& Collins, 2004). In particular, it has been suggested that the small and simple bodies of adult actinulids resemble early developmental stages of trachylines (e.g. Swedmark, 1964; Bouillon \& Boero, 2000). Gould (1977), for example, holds that actinulids and other interstitial organisms may have attained small body sizes by accelerating sexual maturation (paedomorphosis through progenesis), which he regarded as an important adaptive response for inhabiting minute interstitial spaces.

Paedomorphic species have been notoriously difficult for phylogenetic analyses based on morphology (Wiens et al., 2005) and molecular data can be particularly important for such cases. Our analyses consistently place Halammohydra within Trachylina (Figures 4-8) and confirm earlier suggestions that actinulids are related to Narco- and Trachymedusae. Specifically, ML analyses of LSU (Figure 7, right) and combined data (Figure 8) indicate that Halammohydra falls within the family Rhopalonematidae (Trachymedusae). Although adult rhopalonematids are typical planktonic trachyline medusae, some early developmental stages are similar to the adult Halammohydra. For example, developing medusae of the rhopalonematid Aglaura hemistoma resemble adult actinulids in having an elongated and flagellated actinuloid body shape bearing long tentacles (Metschnikoff, 1886). Although trachyline medusae are usually planktonic, the evolution of the interstitial Halammohydra from a trachyline ancestor may have followed a shift from a holopelagic to a pelago-benthic or holobenthic life cycle. As mentioned above, several trachyline species live pelago-benthic lifestyles. It is conceivable that the evolution of a similar epibenthic habitat in the ancestor of actinulids may have preceded the invasion of the interstitial environment.

It remains to be seen how our understanding of actinulidan evolution will be refined when samples of Otohydra become 
available for DNA-based analyses. Species of the latter genus share with Halammohydra the flagellated/ciliated actinuloid body with ontogenetically similar (ecto-endodermal) statocysts. However, the two groups have some significant differences, with Otohydra lacking a nerve ring and an adhesive organ, being hermaphroditic, and possessing two types of tentacles (Swedmark \& Teissier, 1958; Swedmark, 1964; Clausen, 1971). Elucidating the phylogenetic placement of Otohydra remains an important step towards a better understanding of the patterns and processes that resulted in the invasion of the interstitial environment within Trachylina.

\section{Scope of Narcomedusae}

The enigmatic intracellular parasitic cnidarian Polypodium hydriforme (see Raikova, 1994) has sometimes been referred to Narcomedusae (e.g. Hyman, 1940), but unpublished analyses suggest that it is not part of this group (Evans et al., in preparation). Therefore, just four families make up Narcomedusae (Schuchert, 2007). Three families, Aeginidae, Cuninidae and Tetraplatiidae, are sampled here, whereas Solmarisidae is not. The name Tetraplatiidae first appeared in print in Daly et al. (2007) as a nomen nudum, but the taxonomic authority was erroneously stated to be Schuchert, 2007 in reference to Schuchert's (2007) Hydrozoan Directory website. We take the opportunity to formally establish the new family Tetraplatiidae, with its type genus being Tetraplatia Busch, 1851. Its members are readily distinguished by the possession of four distinctive swimming lappets arising from a groove that divides their worm-like bodies into aboral and oral halves.

Our analyses suggest that our sampled representatives of Narcomedusae are monophyletic, though support for this hypothesis is only moderate (Figures 6-8). We find no strong evidence for the monophyly of Aeginidae or Cuninidae. However, support for most relevant nodes is weak and so it does not appear that our analyses contradict monophyly of these families, with one exception. In most of our analyses, the worm-shaped Tetraplatia is shown to have a close relationship with Aegina citrea and Solmundella bitentaculata. The sister to these three species, among our samples, appears to be Solmissus marshalli. Thus, Tetraplatia and by extension the family Tetraplatiidae appears to fall within Aeginidae. As with all the subgroups dealt with in the present paper, additional sampling should further enhance understanding of the phylogeny and evolution of Narcomedusae.

\section{Concluding remarks}

Important questions remain about how to best classify trachyline taxa in light of the phylogenetic analyses presented here. Because our taxon sampling is relatively sparse, formal recommendations seem inappropriate at this time. However, our limited sampling suggests that Trachymedusae is (at least) diphyletic, suggesting that this taxon will need to either have its meaning modified or be discarded. Because Limnomedusae is paraphyletic with respect to the trachymedusan family Geryoniidae, Limnomedusae will also need to have its meaning altered to take these, and forthcoming, findings into account.

Finally, future sampling of molecular data will no doubt be used to clarify species boundaries within trachyline cnidarians. Our data are extremely limited in this regard, but reporting of a few observations are warranted. We note several substantial genetic divergences within what are currently thought to be single species. First, both mitochondrial $16 \mathrm{~S}$ and nuclear SSU data taken from Liriope tetraphylla collected in California and the Caribbean (Panama) show significant divergences ( $P$ distances $>11 \%$ for $16 \mathrm{~S}$ and $>0.3 \%$ for SSU) likely indicating at least some crypsis in this cosmopolitan species. Similarly, Tetraplatia volitans and Tetraplatia sp. from California and Japan, respectively, have mitochondrial $16 \mathrm{~S}$ sequences that differ by nearly $6 \%$, exceeding typical intraspecific differences measured for other hydrozoans (Schuchert, 2005; Govindarajan et al., 2005; Miglietta et al., 2007). Visual inspection of Tetraplatia sp. specimens from Japan suggests that these do not fit the description of $T$. chuni, the only other named species in the genus, but rather that of $T$. volitans, suggesting that this latter name may be being used to refer to at least two distinct species. In contrast, very little to no genetic divergence was revealed in samples of Crossota rufobrunnea and Pantachogon haeckeli (including some unusual colour forms; Figure $1 \mathrm{H}, \mathrm{I}$ ) from California and Japan, and Aglaura hemistoma samples from Japan and the Mediterranean Sea. The geographical distributions of trachyline hydrozoans, as well as the factors controlling them, remain open and interesting questions for further research.

\section{ACKN口WLEDGEMENTS}

We gratefully acknowledge support from the US National Science Foundation (NSF) Assembling the Tree of Life Grant 0531779 (to P.C., A.G.C., and D. Fautin). We also thank: three anonymous referees for reviewing an earlier version of the MS; P. Schuchert for providing DNA extractions; C. Mah and $\mathrm{K}$. Halanych for collecting medusae in Antarctica through support from a NSF grant (OPP-0338218 to KH); the Smithsonian's Marine Science Network and R. Collin for supporting the collection of specimens; the Smithsonian's Laboratory of Analytical Biology for the use of its computer cluster to conduct phylogenetic analyses; E. Strong for the use of a computer to conduct phylogenetic analyses; N. Evans for developing several new LSU primers; Lynne Christianson, the David and Lucile Packard Foundation and the ROVs 'Tiburon' and 'Ventana' for support used to collect specimens; D. Calder, P. Schuchert, S. Cairns and A. Kohn for consultation on how best to handle the nomenclatural issues surrounding the name Tetraplatiidae; and, NSF (PEET DEB-9978086) and FAPESP (06/02960-8/05821-9/60327-0) for financial support for A. Lindner.

\section{REFERENCES}

Bouillon J. (1957) Limnocnida congoensis nouvelle espece de Limnomeduse du bassin du Congo. Revue de Zoologie et de Botanique Africaines 56, 388-395.

Bouillon J. (1985) Essai de classification des Hydropolypes - Hydromeduses (Hydrozoa-Cnidaria). Indo-Malayan Zoology 1, 29-243.

Bouillon J. (1987) Considérations sur le développement des Narcoméduses et sur leur position phylogénétique. Indo-Malayan Zoology 4, 189-278.

Bouillon J. and Boero F. (2000) The Hydrozoa: a new classification in the light of old knowledge. Thalassia Salentina 24, 1-45. 
Bouillon J. and Deroux G. (1967) Remarques sur des Cnidaires du type de Microhydrula pontica Valkanov 1965, trouvés a Roscoff. Cahiers de Biologie Marine 8, 253-272.

Brooks W.K. (1886) Life history of the Hydromedusae. A discussion of the medusae and of the significance of metagenesis. Memoirs of the Boston Society of Natural History 3, 359-430.

Browne E.T. and Kramp P.L. (1939) Hydromedusae from the Falkland Islands. Discovery Reports XVIII, 265-322.

Castresana J. (2000) Selection of conserved blocks from multiple alignments for their use in phylogenetic analysis. Molecular Biology and Evolution 17, 540-552.

Clausen C. (1971) Interstitial Cnidaria: present status of their systematics and ecology. Smithsonian Contributions to Zoology 76, 1-8.

Collins A.G. (2002) Phylogeny of Medusozoa and the evolution of cnidarian life cycles. Journal of Evolutionary Biology 15, 418-432.

Collins A.G., Schuchert P., Marques A.C., Jankowski T., Medina M. and Schierwater B. (2006a) Medusozoan phylogeny and character evolution clarified by new large and small subunit rDNA data and an assessment of the utility of phylogenetic mixture models. Systematic Biology 55, 97-115.

Collins A.G., Bentlage B., Matsumoto G.I., Haddock S.H.D., Osborn K. and Schierwater B. (2006b) Solution to the phylogenetic enigma of Tetraplatia, a worm-shaped cnidarian. Biology Letters 2, 120-124.

Cunningham C.W. and Buss L.W. (1993) Molecular evidence for multiple episodes of pedomorphosis in the family Hydractiniidae. Biochemical Systematics and Ecology 21, 57-69.

Daly M., Brugler M.R., Cartwright P., Collins A.G., Dawson M.N., Fautin D.G., France S.C., McFadden C.S., Opresko D.M., Rodrigues E., Romano S.L. and Stake J.L. (2007) The phylum Cnidaria: a review of phylogenetic patterns and diversity 300 years after Linnaeus. Zootaxa 1668, 127-182.

Edgar R.C. (2004) MUSCLE: multiple sequence alignment with high accuracy and high throughput. Nucleic Acids Research 32, 1792- 1797.

Edwards C. (1973) Contributory thoughts on form, function, habitat and classification of hydroids and hydromedusae. Publications of the Seto Marine Biological Laboratory 20, 11-22.

Gould S.J. (1977) Ontogeny and phylogeny. Cambridge, MA: Belknap Press.

Govindarajan A.F., Halanych K.M. and Cunningham C.W. (2005) Mitochondrial evolution and phylogeography in the hydrozoan Obelia geniculata (Cnidaria). Marine Biology 146, 213-222.

Hand C. (1955) A study of the structure, affinities, and distribution of Tetraplatia volitans Busch (Coelenterata: Hydrozoa: Pteromedusae). Pacific Science 9, 332-348.

Hashimoto H. (1981) The fresh water hydroid Astrohydra japonica new genus new species. Annotationes Zoologicae Japoneses 54, 207-212.

Hashimoto H. (1985) Medusa of fresh-water hydroid Astrohydra japonica. Annotationes Zoologicae Japoneses 2, 761-766.

Hyman L.H. (1940) The invertebrates, vol. 1. Protozoa through Ctenophora. New York: McGraw-Hill.

Jankowski T. (2001) The freshwater jellyfish of the world-a taxonomic and systematic literature study. Hydrobiologia 462, 91-113.

Jankowski T., Collins A.G. and Campbell R. (2008) Global diversity of inland water cnidarians. Hydrobiologia 595, 35-40.

Jarms G. and Tiemann H. (1996) On a hydropolyp without tentacles Microhydrula limopsicola n. sp., epibiontic on bivalve shells from the Antarctic. Scientia Marina 60, 109-115.
Kikinger R. and Salvini-Plawen L.V. (1995) Development from polyp to stauromedusa in Stylocoronella (Cnidaria: Scyphozoa). Journal of the Marine Biological Association of the United Kingdom 75, 899-912.

Kramp P.L. (1938) Die meduse von Ostroumovia inkermanica (Pal.-Ostr.) und die systematische stellung der olindiiden. Zoologischer Anzeiger 122, 103-108.

Marques A.C. and Collins A.G. (2004) Cladistic analysis of Medusozoa and cnidarian evolution. Invertebrate Biology 123, 23-42.

Medina M., Collins A.G., Silberman J.D. and Sogin M.L. (2001) Evaluating hypotheses of basal animal phylogeny using complete sequences of large and small subunit rRNA. Proceedings of the National Academy of Sciences of the United States of America 98, 9707-9712.

Medlin L., Elwood H.J., Stickel S. and Sogin M.L. (1988) The characterization of enzymatically amplified eukaryotic $16 \mathrm{~S}$-like rRNA-coding regions. Gene 71, 491-499.

Metschnikoff E. (1886) Embryologische Studien an Medusen. Ein Beitrag Zur Genealogie der Primitiv-Organe. Wien: Alfred Hölder.

Miglietta M.P., Piraino S., Kubato S. and Schuchert P. (2007) Species in the genus Turritopsis (Cnidaria, Hydrozoa): a molecular evaluation. Journal of Zoological Systematics and Evolutionary Research 45, 11-19.

Mühlhardt C. (2003) Molekularbiologie-genomics. Heidelberg: Spektrum Akademischer Verlag.

Naumov D.V. (1960) Hydroids and hydromedusae of the USSR. Jerusalem: Israel Programme for Scientific Translations. [Translated from Russian (1969).]

Norenburg J.L. and Morse M.P. (1983) Euphysa ruthae (Athecata, Corymorphidae) sp. n., a psammophilic solitary hydroid with statocysts and reversed polarity buds, with a discussion of euphysine characters. Transactions of the American Microscopical Society $102,1-17$.

Petersen K.W. (1990) Evolution and taxonomy in capitate hydroids and medusae (Cnidaria: Hydrozoa). Zoological Journal of the Linnaean Society 100, 101-231.

Posada D. and Crandall K.A. (1998) MODELTEST: testing the model of DNA substitution. Bioinformatics 14, 817-818.

Raikova E.V. (1994) Life cycle, cytology, and morphology of Polypodium hydriforme, a coelenterate parasite of the eggs of acipenseriform fishes. Journal of Parasitology 80, 1-22.

Rees W.J. (1958) The relationships of Moerisia lyonsi Boulenger and the family Moerisiidae, with capitate hydroids. Proceedings of the Zoological Society of London 130, 537-545.

Remane A. (1927) Halammohydra, ein eigenartiges Hydrozoon der Nordund Ostsee. Zeitschrift für Morphologie und Ökologie der Tiere 7 , $643-677$.

Salvini-Plawen L.V. (1987) Mesopsammic Cnidaria from Plymouth (with systematic notes). Journal of the Marine Biological Association of the United Kingdom 67, 623-637.

Schuchert P. (1996) The marine fauna of New Zealand: athecate hydroids and their Medusae (Cnidaria: Hydrozoa). Wellington: New Zealand Oceanographic Institute.

Schuchert P. (1998) How many hydrozoan species are there? Zoologische Verhandelingen 323, 209-219.

Schuchert P. (2005) Species boundaries in the hydrozoan genus Coryne Molecular Phylogenetics and Evolution 36, 194-199.

Schuchert P. (2007) The Hydrozoa Directory, Version 15, September 2007. (http://www.ville-ge.ch/musinfo/mhng/hydrozoa/hydrozoa-directory. htm). 
Swedmark B. (1964) The interstitial fauna of marine sand. Biological Reviews 39, 1-42.

Swedmark B. and Teissier G. (1958) Otohydra vagans n. g., n. sp., hydrozoaire des sables, apparanté aux Halammohydridées. Comptes Rendus Hebdomadaires des Séances de l'Académie des Sciences de Paris 247, $238-240$.

Swedmark B. and Teissier G. (1966) The Actinulida and their evolutionary significance in the Cnidaria. In Rees W.J. (ed.) The Cnidaria and their evolution. London: Academic Press, pp. 119-133.

Swofford D.L. (2002) PAUP*: Phylogenetic Analysis Using Parsimony (* and Other Methods), version 4. Sunderland, MA: Sinauer Associates.

Voigt O., Collins A.G., Pearse V.B., Hadrys H. and Schierwater B. (2004) Placozoa-no longer a phylum of one. Current Biology 14, R944-R945.

Werner B. (1965) Halammohydra Remane, Medusennatur und Stellung im System. Zoologischer Anzeiger Supplement 28, 163-177.

Wiens J.J., Bonett R.M. and Chippindale P.T. (2005) Ontogeny discombobulates phylogeny: paedomorphosis and higher-level salamander phylogeny. Systematic Biology 54, 91-110.
Zagal C.J. (2004) Population biology and habitat of the stauromedusan Haliclystus auricula in southern Chile. Journal of the Marine Biological Association of the United Kingdom 84, 331-336.

and

Zwickl D.J. (2006) Genetic algorithm approaches for the phylogenetic analysis of large biological sequence datasets under the maximum likelihood criterion. $\mathrm{PhD}$ thesis, The University of Texas, Austin, USA.

\section{Correspondence should be addressed to:}

Allen G. Collins

NMFS, National Systematics Laboratory

National Museum of Natural History

MRC-153, Smithsonian Institution

PO Box 37012, Washington

DC 20013-7012, USA

email: CollinsA@SI.edu 